Abstracta Iranica Abstracta Iranica

Revue bibliographique pour le domaine irano-aryen

Volume 32-33 | 2013

Comptes rendus des publications de 2009-2010

\title{
Karin Mosig-Walburg. Sonderprägungen Khusro II. (590-628): Innenpolitische Propaganda vor dem Hintergrund des Krieges gegen Byzanz
}

Nikolaus Schindel

\section{(2) OpenEdition \\ 1 Journals}

Electronic version

URL: http://journals.openedition.org/abstractairanica/40561

DOI: 10.4000/abstractairanica.40561

ISSN: 1961-960X

Publisher:

CNRS (UMR 7528 Mondes iraniens et indiens), Éditions de l'IFRI

\section{Printed version}

Date of publication: 1 December 2013

ISSN: 0240-8910

\section{Electronic reference}

Nikolaus Schindel, « Karin Mosig-Walburg. Sonderprägungen Khusro II. (590-628): Innenpolitische

Propaganda vor dem Hintergrund des Krieges gegen Byzanz », Abstracta Iranica [Online], Volume 32-33 |

2013, document 192, Online since 01 July 2016, connection on 03 October 2020. URL : http://

journals.openedition.org/abstractairanica/40561; DOI : https://doi.org/10.4000/abstractairanica. 40561

This text was automatically generated on 3 October 2020.

Tous droits réservés 


\title{
Karin Mosig-Walburg. Sonderprägungen Khusro II. (590-628): Innenpolitische Propaganda vor dem Hintergrund des Krieges gegen Byzanz
}

\author{
Nikolaus Schindel
}

\section{REFERENCES}

Karin Mosig-Walburg. « Sonderprägungen Khusro II. (590-628): Innenpolitische Propaganda vor dem Hintergrund des Krieges gegen Byzanz ». Res Orientales XVIII, Sources pour l'histoire et la géographie du monde iranien (224-710). Bures-sur-Yvette / Leuven, GECMO / Peeters Press, 2009, p. 185-208.

1 The author discusses the special issues of the Sasanian king Hosrow II (590-628) that feature a bust in flames on the reverse. They were struck intermittently from Hosrow's regal years 21 to 37 (610/1-626/7). According to the author, all these coins are evidence of the Persian nobility's opposition to Hosrow's war against the Byzantines, an assumption that, not supported by other sources, is, in fact, very unlikely since the Sasanians were remarkably successful for a long time during this war. Her reading of the legend on the reverse seems doubtful. 


\section{AUTHORS}

NIKOLAUS SCHINDEL

Österreichische Akademie der Wissenschaften, Wien 